\title{
AMPA Receptor Channels with Long-Lasting Desensitization in Bipolar Interneurons Contribute to Synaptic Depression in a Novel Feedback Circuit in Layer 2/3 of Rat Neocortex
}

\author{
A. Rozov, ${ }^{1}$ J. Jerecic, ${ }^{2}$ B. Sakmann, ${ }^{1}$ and N. Burnashev ${ }^{1}$ \\ ${ }^{1}$ Abt. Zellphysiologie and ${ }^{2}$ Abteilung Molekulare Neurobiologie, Max-Planck-Institut für medizinische Forschung, D-69120 \\ Heidelberg, Germany
}

A novel, local inhibitory circuit in layer $2 / 3$ of rat somatosensory cortex is described that connects pyramidal cells reciprocally with GABAergic vasoactive intestinal polypeptide-immunoreactive bipolar interneurons. In paired whole-cell recordings, the glutamatergic unitary responses (EPSPs or EPSCs) in bipolar cells evoked by repetitive $(10 \mathrm{~Hz})$ stimulation of a pyramidal cell show strong frequency-dependent depression. Unitary IPSPs evoked in pyramidal cells by repetitive stimulation of bipolar cells, on average, maintained their amplitude. This suggests that the excitatory synapses on bipolar cells act as a low-pass filter in the reciprocal pyramid-to-bipolar circuit. The EPSCs in bipolar cells are mediated predominantly by AMPA receptor (AMPAR) channels. AMPARs desensitize rapidly and recover slowly from desensitization evoked by a brief pulse of glutamate. In slices, reduction of AMPAR desensitization by cyclothiazide (50-100 $\mu \mathrm{M}$ ) or conditioning steady-state desensitization induced by application of extracellular AMPA (50 nM) or glutamate $(50 \mu \mathrm{M})$ strongly reduced synaptic depression. It is concluded that in the local circuits between pyramidal and bipolar cells the desensitization of AMPARs in bipolar cells contributes to low-pass feedback inhibition of layer $2 / 3$ pyramidal neurons by bipolar cells.

Key words: neocortex; interneurons; neuronal circuit; synaptic depression; AMPA receptors; desensitization
Neurons with a bipolar dendritic arbor constitute a morphologically identified type of GABAergic inhibitory interneurons in the neocortex. These cells control the excitability of pyramidal cells via GABAergic synapses. One subtype of interneurons of layer $2 / 3$, designated as "bitufted" interneurons, express the neuropeptide somatostatin. In these interneurons the unitary EPSPs evoked by pyramidal cell stimulation show frequency-dependent facilitation (Markram et al., 1998; Reyes et al., 1998). Other subtypes of inhibitory neurons with bipolar dendritic morphology express vasoactive intestinal polypeptide (VIP) or cholecystokinin (CCK). They respond with different patterns of action potentials (APs) during depolarizing current injection (Kawaguchi, 1993, 1995; Kawaguchi and Kubota, 1996, 1997; Porter et al., 1998). How the "bipolar" cells are connected to other neocortical neurons and what determines the efficacy and frequencydependent short-term modulation of these connections is not well understood.

By making simultaneous dual recordings from bipolar and other neocortical neurons, we describe one subtype of bipolar VIP-immunopositive interneurons that are located in layer $2 / 3$ of the somatomotor cortex that show strong frequency-dependent depression of the unitary EPSPs evoked by repetitive stimulation of layer $2 / 3$ pyramidal cells. These bipolar interneurons form a feedback loop with pyramidal cells in layer $2 / 3$ via GABAergic

\footnotetext{
Received Dec. 22, 2000; revised Aug. 6, 2001; accepted Aug. 8, 2001.

We thank Drs. Nathan Urban and Troy Margrie for their comments on this manuscript.

Correspondence should be addressed to N. Burnashev, Department of Neurophysiology, Faculty of Biology, Vrije University Amsterdam, De Boelelaan 1087, 1081 HV Amsterdam, The Netherlands. E-mail: nail@bio.vu.nl.

A. Rozov's present address: Department of Neurophysiology, Faculty of Biology, Vrije University Amsterdam, De Boelelaan 1087, 1081 HV Amsterdam, The Netherlands.

Copyright (ㄷ) 2001 Society for Neuroscience $\quad 0270-6474 / 01 / 218062-10 \$ 15.00 / 0$
}

synapses. They express AMPAR channels characterized by fast inactivation and desensitization in response to short pulses of glutamate. However, the time course of recovery from desensitization of these channels is comparatively slow. This local pyramid-to-bipolar circuit is the first example in the neocortex where the effectiveness of a feedback loop is dominated by the desensitization properties of postsynaptic AMPAR channels.

\section{MATERIALS AND METHODS}

Brain slices. Transverse neocortical slices of the somatosensory cortex of $300 \mu \mathrm{m}$ thickness were prepared from the brains of 14-d-old Wistar rats killed by decapitation. During recordings, slices were maintained at room temperature $\left(22-24^{\circ} \mathrm{C}\right)$ in extracellular solution consisting of (in $\mathrm{mM}$ ): $125 \mathrm{NaCl}, 2.5 \mathrm{KCl}, 25$ glucose, $25 \mathrm{NaHCO}_{3}, 1.25 \mathrm{NaH}_{2} \mathrm{PO}_{4}, 2 \mathrm{CaCl}_{2}$, and $1 \mathrm{MgCl}_{2}$ (pH 7.2 when bubbled with carbogen). Neurons were visualized via a $40 \times$ water immersion objective using infrared differential interference contrast (IR-DIC) video microscopy (Stuart et al., 1993).

Electrophysiology. Whole-cell voltage or/and current recordings were performed simultaneously from two neurons using pipettes with resistance of 5-7 $\mathrm{M} \Omega$ when filled with (in $\mathrm{mm}$ ): $105 \mathrm{~K}$ gluconate, $30 \mathrm{KCl}, 4$ Mg-ATP, 10 phosphocreatine, 0.3 GTP, and 10 HEPES, pH 7.3, KOH, $293 \mathrm{mOsm}$. In synaptically connected neurons, suprathreshold intracellular stimulation of presynaptic cells evoked depolarizing EPSPs and IPSPs. In some experiments low-chloride intracellular solution was used so that the IPSPs hyperpolarized. This solution contained (in mM): 130 K gluconate, $10 \mathrm{Na}$ gluconate, $4 \mathrm{NaCl}, 4 \mathrm{Mg}$-ATP, 4 phosphocreatine, 0.3 GTP, and 10 HEPES, pH 7.3, KOH, 305 mOsm. Both depolarizing and hyperpolarizing IPSPs were analyzed. Presynaptic cells were stimulated with a $10 \mathrm{~Hz}$ train of two or three suprathreshold current pulses. Trains were delivered at intervals of $>7 \mathrm{sec}$. Voltage and current traces shown are averages of 50-100 sweeps. Stimulus delivery and data acquisition was performed using Pulse software (Heka Elektronik, Lambrecht, Germany). All analyses were performed using IgorPro software (WaveMetrics, Lake Oswego, OR). After paired recordings were made, nucleated patches (Sather et al., 1992) were pulled from the target cell, and glutamate (1 mM) was applied using a piezo-controlled (piezo P 245.70; Physik Instrumente, Waldbronn, Germany) fast application system with a double-barrel application pipette (Colquhoun et al., 1992). Durations of 
the glutamate pulses were 2 or $50 \mathrm{msec}$. AMPAR-mediated currents in patches were recorded in the presence of $100 \mu \mathrm{M}$ D-AP-5. Relative $\mathrm{Ca}^{2+}$ to $\mathrm{Na}^{+}$permeability was determined as in Brusa et al. (1995). In these experiments the standard extracellular solution was (in $\mathrm{mM}$ ): $135 \mathrm{NaCl}$, 5.4 KCl, $1.8 \mathrm{CaCl}_{2}, 1 \mathrm{MgCl}_{2}$, and $10 \mathrm{HEPES}, \mathrm{pH} 7.2, \mathrm{NaOH}$. High $\mathrm{Ca}^{2+}$ extracellular solution contained (in $\mathrm{mM}$ ): $105 \mathrm{~N}$-methyl-D-glucamine (NMDG), $30 \mathrm{CaCl}_{2}, 5 \mathrm{HEPES}, \mathrm{pH} \mathrm{7.2,} \mathrm{HCl}$. Intracellular solution contained (in mM): 135 CsCl, 0.5 EGTA, 4 Mg-ATP, 5 HEPES, pH 7.2, $\mathrm{NaOH}$. In other experiments with nucleated patches intracellular solution was the same as for synaptic recordings.

Morphological reconstructions. Cell pairs were filled with biocytin (2\%) added to the intracellular pipette solution. Morphological reconstruction of labeled cells after fixation and processing (Markram et al., 1997) was subsequently made using the Neurolucida tracing program (MicroBrightField, Colchester, VT).

Immunocytochemistry. After individual cells had been filled with biocytin, slices were post-fixed with $4 \%$ paraformaldehyde overnight at $4{ }^{\circ} \mathrm{C}$. Slices were embedded in $4 \%$ agar (Fluka, Buchs, Switzerland), subsliced into $50 \mu \mathrm{m}$ thin sections on a vibratome (VT1000S; Leica, Heidelberg,

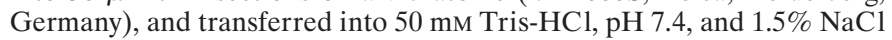
(TBS). Sections were permeabilized in TBS and $0.4 \%$ Triton X-100 (Sigma, Steinheim, Germany) for 30 min followed by preincubation in TBS, $4 \%$ normal goat serum (NGS), and $0.2 \%$ Triton X-100 for $30 \mathrm{~min}$, and incubation in $2 \%$ NGS and $0.1 \%$ Triton X-100 at $4^{\circ} \mathrm{C}$ overnight with VIP rabbit antiserum (1:100; Incstar, Stillwater, MN). Sections were washed three times for $10 \mathrm{~min}$ with cold TBS and incubated for $2.5 \mathrm{hr}$ in goat anti-rabbit Cy3-conjugated secondary antibody (1:200) and fluorescein-isothiocyanate (FITC)-conjugated avidin (1:100). Sections were washed twice for $10 \mathrm{~min}$ in TBS and 1\% NGS and twice in TBS. After a brief rinse in $10 \mathrm{~mm}$ Tris-HCl, pH 7.4, sections were air-dried and mounted in Mowiol (Polysciences, Warrington, PA). Immunostained sections were visualized under epifluorescent illumination with an Axioplan 2 microscope (Zeiss, Jena, Germany).

Data in the graphs, tables, and text are given as the mean \pm SD.

\section{RESULTS}

\section{Anatomical and functional signature of reciprocal pyramid to bipolar cell connections}

Figure $1 A$ (right panel) shows the appearance in the IR-DIC video image in layer $2 / 3$ of the soma and the proximal portions of both the apical and basal dendrites of a bipolar interneuron that received strongly depressing glutamatergic excitatory input from a layer $2 / 3$ pyramidal neuron (Fig. 1 A, left panel). These bipolar interneurons were distinguished from the bitufted interneurons that receive facilitating input from pyramidal neurons by the different pattern of action potentials (APs) that developed during depolarizing somatic current injection. Typically at resting membrane potentials (approximately $-70 \mathrm{mV}$ ) the AP pattern was characterized by an initial fast burst of three APs (average interspike intervals, $12 \pm 4 \mathrm{msec}$ and $26 \pm 4 \mathrm{msec} ; n=5$ ) followed by a regular spike pattern at lower frequency (interspike interval, $75 \pm 15 \mathrm{msec} ; n=5)$. In most cells a long interval (117 $\pm 44 \mathrm{msec}$; $n=5$ ) between the initial burst and the regularly spiking part of the AP train was apparent (Fig. $1 B$, top trace). With the same current injection $(100 \mathrm{pA})$ into the cell that was depolarized to $-60 \mathrm{mV}$ the interval after the burst was no longer apparent or became less pronounced (Fig. 1B, bottom trace), and the frequency of the regular spikes became somewhat higher (interspike interval, $63 \pm 8 \mathrm{msec} ; n=6$ ). These bipolar cells thus show an AP pattern similar to those designated as irregular spiking (IS) cells (Porter et al., 1998). This type of bipolar neurons was postsynaptic to pyramidal cells and was further characterized by the marked frequency dependent depression of unitary EPSPs, evoked by repetitive pyramidal cell stimulation (Fig. 1C).

\section{Dendritic and axonal morphology}

To correlate the functional and morphological properties of this type of interneurons, we filled both presynaptic and postsynaptic

\section{A}
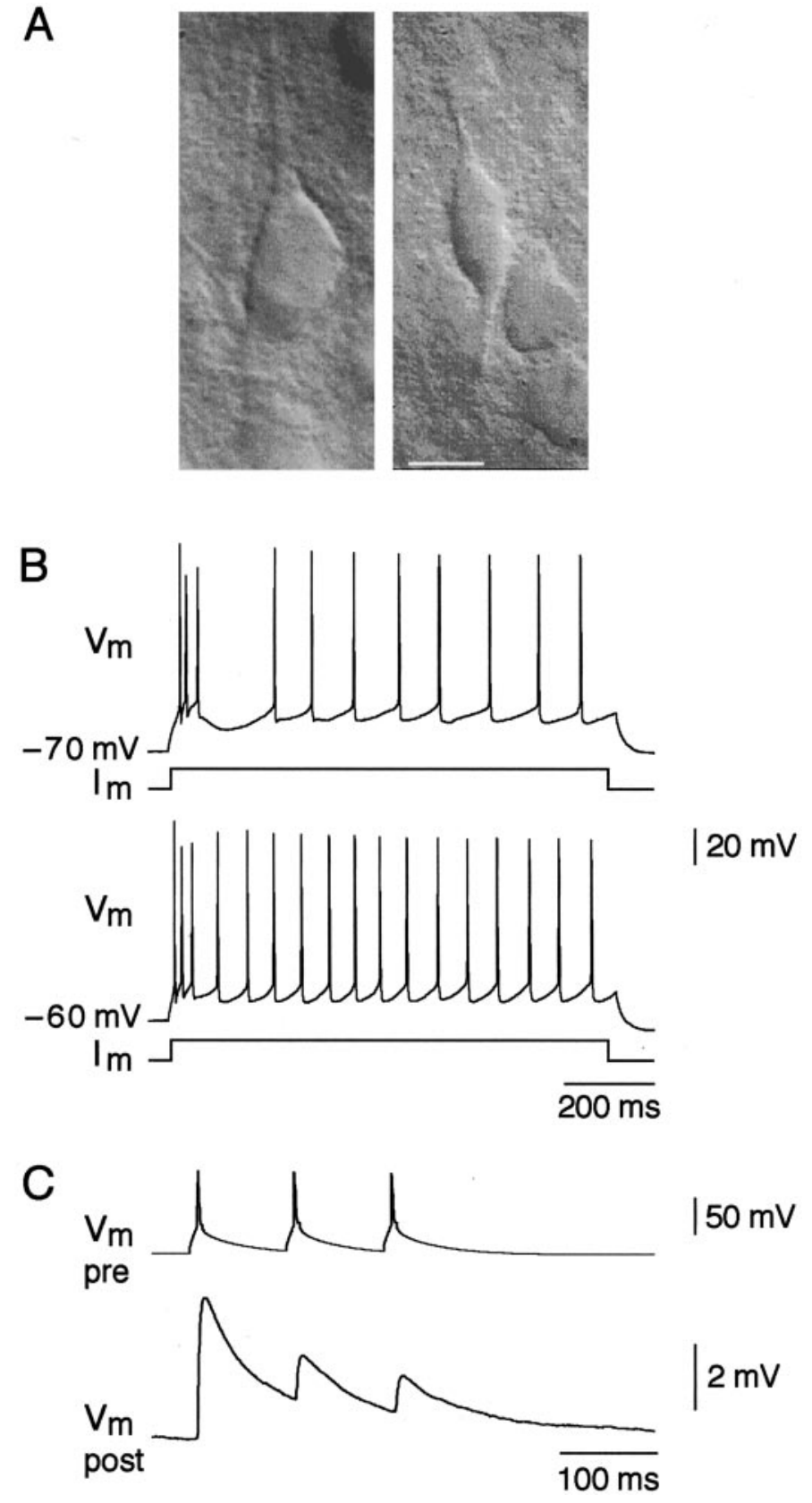

Figure 1. Morphological and functional signature of bipolar interneurons. $A$, Representative IR-DIC image of a pyramidal cell (left) and a bipolar cell (right) in layer $2 / 3$ region of rat neocortex. Scale bar, $10 \mu \mathrm{m}$. $B$, Action potential patterns of a bipolar cell after depolarizing current injection of the same value $(100 \mathrm{pA})$ at resting potential $(-70 \mathrm{mV}$; top trace) and at $-60 \mathrm{mV}$ (bottom trace). $C$, Short-term depression of EPSPs (bottom trace) in response to three action potentials $(10 \mathrm{~Hz}$; top trace) evoked in synaptically connected pyramidal cell.

neurons with biocytin. We reconstructed the dendritic and the axonal arbors of these neurons and found that in all bipolar neurons analyzed $(n=5)$ the AP pattern, and depressing EPSPs were associated with a bipolar vertically oriented dendritic arborization (Fig. $2 A$, Table 1). The axonal arbor of these cells also span primarily in the vertical field in the granular and infragranular layers (down to layer 6) of the cortex (Fig. 2A, Table 1). Ten of eleven bipolar interneurons identified by these morphological and physiological properties were immunopositive for VIP, pro- 


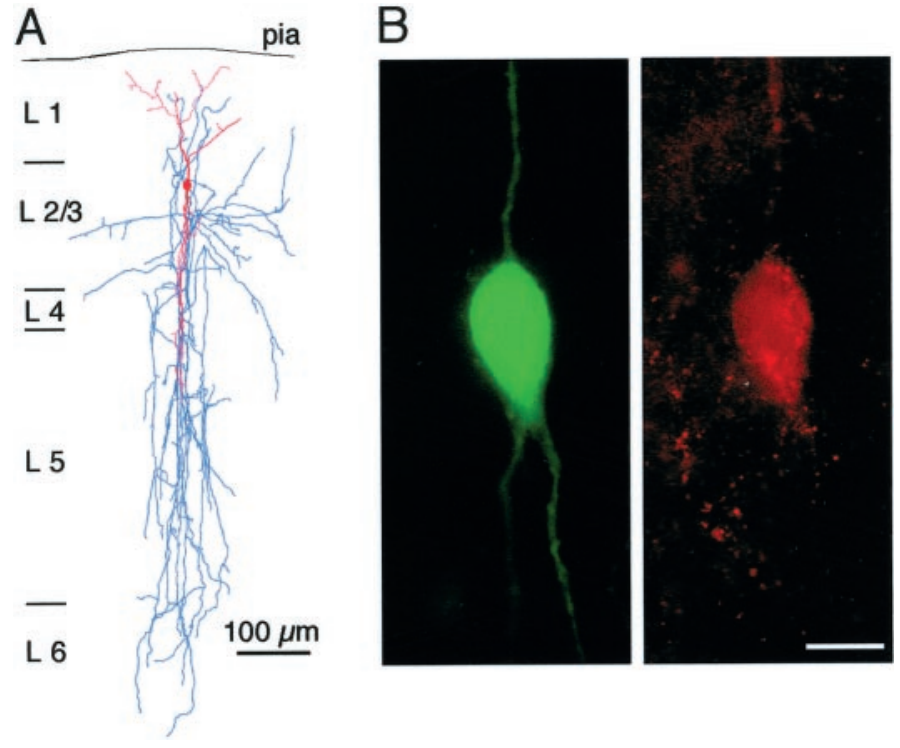

Figure 2. Anatomical and immunocytochemical identification of bipolar interneurons. $A$, Dendritic (red) and axonal (blue) arbor morphology of a biocytin-labeled bipolar interneuron. $B$, Digital micrograph of a biocytinlabeled bipolar interneuron visualized by FITC-labeled avidin (left). VIP immunoreactivity of the same cell shown by CY-3 immunofluorescence (right). Scale bar, $10 \mu \mathrm{m}$.

\begin{tabular}{|c|c|c|}
\hline \multirow[t]{2}{*}{ Soma } & Vertical diameter $(\mu \mathrm{m})$ & $20 \pm 2(n=5)$ \\
\hline & Horizontal diameter $(\mu \mathrm{m})$ & $10 \pm 1(n=5)$ \\
\hline \multicolumn{3}{|l|}{ Dendrites } \\
\hline \multirow[t]{2}{*}{ Apical } & Vertical field span $(\mu \mathrm{m})$ & $240 \pm 64(n=5)$ \\
\hline & Horizontal field span $(\mu \mathrm{m})$ & $125 \pm 26(n=5)$ \\
\hline \multirow[t]{2}{*}{ Basal } & Vertical field span $(\mu \mathrm{m})$ & $251 \pm 89(n=5)$ \\
\hline & Horizontal field span $(\mu \mathrm{m})$ & $110 \pm 53(n=5)$ \\
\hline \multirow[t]{2}{*}{ Axon collaterals } & Total vertical field span $(\mu \mathrm{m})$ & $929 \pm 243(n=5)$ \\
\hline & Horizontal field span $(\mu \mathrm{m})$ & $418 \pm 225(n=5)$ \\
\hline
\end{tabular}

viding an additional cytochemical marker for their identification (Fig. 2B).

\section{Reciprocal connections with pyramidal neurons}

Figure 3, $A$ and $B$, illustrates a biocytin-filled and reconstructed pair of a pyramidal cell and a bipolar cell. In this pair of cells the axon of the pyramidal cell made four putative contacts with the dendrites of bipolar interneuron. Axons of bipolar interneurons also were connected to dendrites of pyramidal cells. Figure 3, C and $D$, shows a biocytin-filled pair of a bipolar and a pyramidal cell. Here the axon collaterals of the bipolar cell made three putative contacts with the basal dendrites of the pyramidal cell. This feedback projection of bipolar to pyramidal neurons was via GABAergic synapses. Bipolar cell APs evoked unitary postsynaptic potentials in pyramidal neurons that were hyperpolarizing in low $\mathrm{Cl}^{-}$intracellular solution (Fig. 4B). Application of bicuculline $(10 \mu \mathrm{M})$ completely blocked the postsynaptic potentials, indicative of $\mathrm{GABA}_{\mathrm{A}}$-mediated IPSPs (data not shown).

We also examined frequency-dependent changes in EPSPs and IPSPs by measuring paired-pulse ratio after pyramidal and bitufted cell stimulation, respectively. At $10 \mathrm{~Hz}$ stimulation the EPSPs recorded from bipolar cells showed synaptic depression
(EPSP2/EPSP1 was $43 \pm 10 \% ; n=18$ ), whereas the pattern of IPSPs evoked in pyramidal neurons differed in different pairs with an average ratio of IPSP2/IPSP1 of $102 \pm 36 \%(n=13)$ (Fig. $4 C$ ). From 13 cell pairs tested for GABA $\mathrm{A}_{\mathrm{A}}$-mediated IPSPs, seven individual pairs were connected reciprocally. Averaged EPSPs and IPSPs recorded from such a pair are shown in Figure $4 B$. Thus, in layer $2 / 3$ of the rat somatosensory cortex along with the previously described GABAergic bitufted and multipolar interneurons (Reyes et al., 1998), bipolar cells form an additional local circuit (Fig. 4A) with neighboring pyramidal neurons.

\section{Functional properties of GluR channels in bipolar interneurons}

To characterize further the function of bipolar interneurons, we compared the properties of glutamate receptor (GluR) channels in these cells with those present in bitufted and multipolar interneurons. Paired whole-cell recordings were first performed to characterize properties of the connection and for identification of the postsynaptic target cell. We then pulled a nucleated patch from the target cell for rapid application of glutamate. Application of brief $(2 \mathrm{msec})$ glutamate $(1 \mathrm{~mm})$ pulses to nucleated patches in $\mathrm{Mg}^{2+}$-free extracellular solution evoked dual component currents in all three cell types. The slow component was blocked by $50 \mu \mathrm{M}$ D-AP-5, a selective blocker of NMDAR channels. The remaining fast component was blocked by $5 \mu \mathrm{M}$ NBQX. The non-NMDAR current recorded during long application (50 $\mathrm{msec}$ ) of glutamate showed strong desensitization that was completely removed by $100 \mu \mathrm{M}$ cyclothiazide (CTZ) (see Fig. 8A,B) but not by Concanavalin A $(0.3 \mathrm{mg} / \mathrm{ml})$. Moreover, currents activated in these patches by kainate did not desensitize (data not shown). Taken together these observations indicate that AMPAR but not kainate receptor channels mediate the fast component of glutamate-evoked current in all three types of interneurons.

Because under physiological conditions at rest, NMDAR channels are mostly blocked by $\mathrm{Mg}^{2+}$, currents through AMPAR channels mediate the main component of EPSC. To determine the possible cell-specific functional properties of AMPAR channels in bipolar cells, we first measured their $\mathrm{Ca}^{2+}$ permeability. In contrast to multipolar and bitufted cells the relative $\mathrm{Ca}^{2+}$ to $\mathrm{Na}^{+}$permeability in a bipolar cell AMPARs was low, as indicated by more negative shift of reversal potentials $(-60.6 \pm 8.8$ $\mathrm{mV} ; n=5$ ) in high $\mathrm{Ca}^{2+}$ solution (Fig. 5, Table 2). In multipolar and bitufted cells the shifts in reversal potentials were $-16 \pm 6.8$ $\mathrm{mV}(n=6)$ and $-12.1 \pm 4.6 \mathrm{mV}(n=10)$, respectively.

Second, the deactivation and desensitization kinetics of the glutamate-mediated current was compared when nucleated patches were exposed to a brief $(2 \mathrm{msec})$ or a long $(50 \mathrm{msec})$ pulse of glutamate. The deactivation time course was not significantly different for all three cell types (Table 2). However, in both bipolar and multipolar cells the desensitization time course was significantly faster than that in bitufted cell, in fact it was almost as fast as the time course of deactivation (Fig. 5, Table 2). Thus, in bipolar and in multipolar cells of the neocortex, the fast synaptic current might be in part terminated by desensitization of AMPARs.

\section{Recovery from receptor desensitization}

To dissect a possible contribution of AMPAR desensitization to synaptic depression, we compared the time course of recovery of glutamate-activated currents from desensitization in nucleated patches with the recovery from depression of evoked EPSPs. Nucleated patches were exposed to brief pulses $(2 \mathrm{msec})$ of $1 \mathrm{~mm}$ 

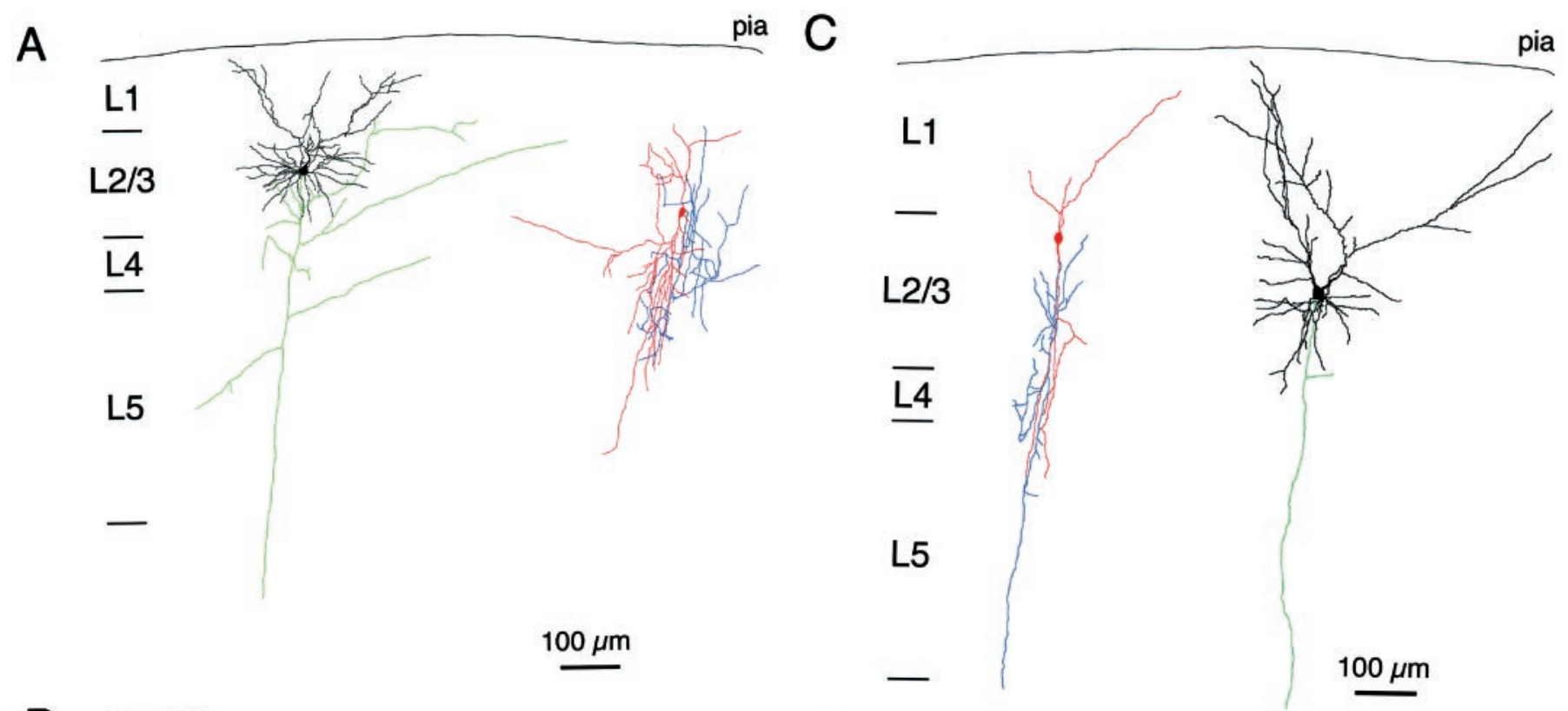

\section{B $\quad \mathrm{P}->\mathrm{BP}$}

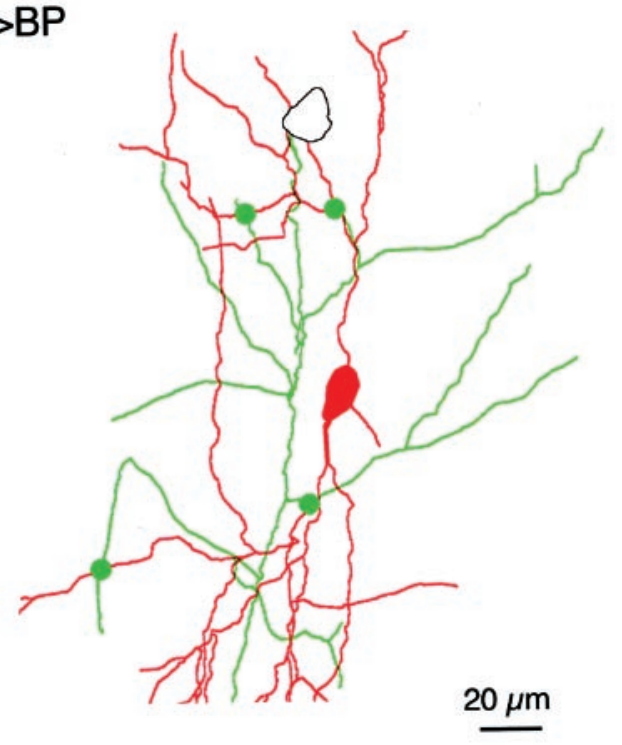

\section{D $\quad B P->P$}

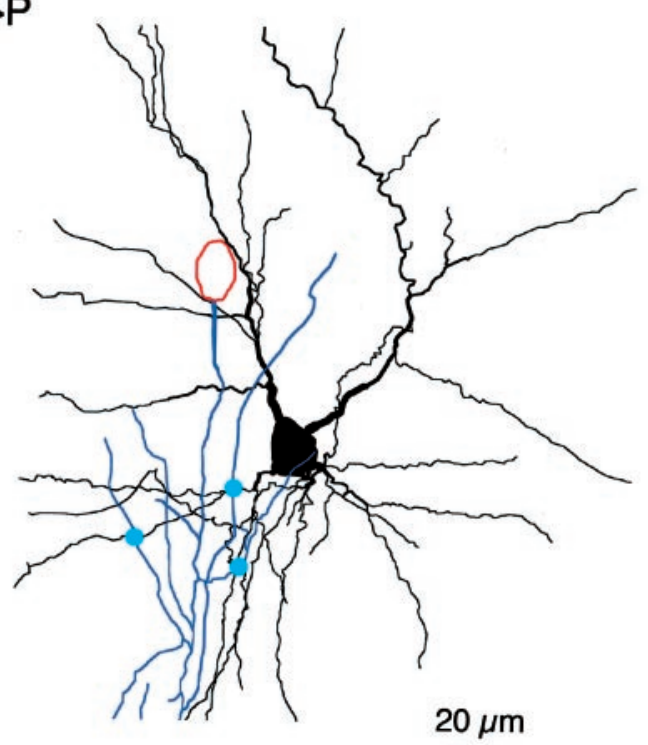

Figure 3. Synaptic connections between bipolar and pyramidal neurons. $A$, Dendritic and axonal arbor morphology of a biocytin-labeled pyramidal neuron (left) making excitatory synaptic connection to bipolar interneuron (right). Two cells are shown separately for clarity. $B$, Four excitatory synaptic connections (green circles) between the axon of the pyramidal neuron (green) and dendrites of the bipolar interneuron (red). The same cells as in $A$ shown on expanded scale. $C$, Dendritic and axonal arbor morphology of a biocytin-labeled bipolar interneuron (left) making inhibitory synaptic connection to pyramidal neuron (right). $D$, Three inhibitory synaptic connections (blue circles) between the axon of the bipolar interneuron (blue) and dendrites of the pyramidal neuron (black). The same cells as in $C$ shown on expanded scale.

glutamate separated by various time intervals (Fig. 6). In bipolar cells AMPAR channels recovered from desensitization only after $5 \mathrm{sec}$, whereas in multipolar and bitufted cells the recovery time was much shorter within $1 \mathrm{sec}$ and $200 \mathrm{msec}$, respectively (Fig. 6, Table 2). In bipolar and multipolar cells, both receiving inputs from pyramidal cells, the time course of recovery from pairedpulse depression (PPD) measured by unitary EPSPs, was almost identical (Fig. 7) with the complete recovery time of $4-5 \mathrm{sec}$. This time course is much slower than the time of recovery from desensitization of AMPARs in multipolar cells, but in bipolar cells it is comparable. At $100 \mathrm{msec}$ time interval (Fig. 6) only $\sim 30 \%$ of AMPARs recovered from desensitization in bipolar cells, whereas almost $70 \%$ in multipolar cells recovered. Thus, at a given stimulation frequency, desensitization of postsynaptic AMPAR channels may contribute more to synaptic depression in bipolar cells than in multipolar cells.

\section{AMPAR desensitization and synaptic depression}

We investigated the possible contribution of AMPAR desensitization to synaptic depression by two approaches. In two classes of synaptic connections we tested first effects on synaptic depression of the reduction of AMPAR desensitization by CTZ and second, the effects of conditioning (increasing) steady-state AMPAR desensitization by low concentrations of either AMPA or glutamate. 


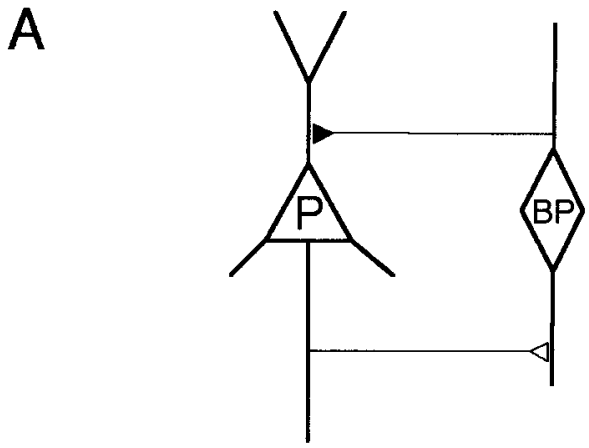

\section{B P $>$ BP}

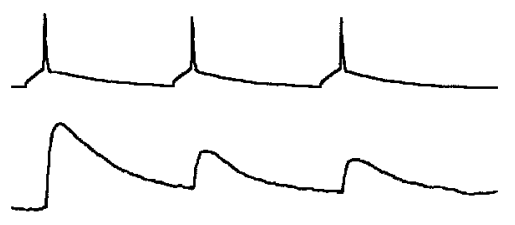

$140 \mathrm{mV}$

$1 \mathrm{mV}$

$\mathrm{BP}->\mathrm{P}$

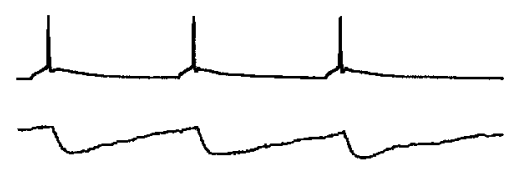

$140 \mathrm{mV}$

$0.4 \mathrm{mV}$

$50 \mathrm{~ms}$

\section{C $\quad \mathrm{P} \rightarrow \mathrm{BP}$}
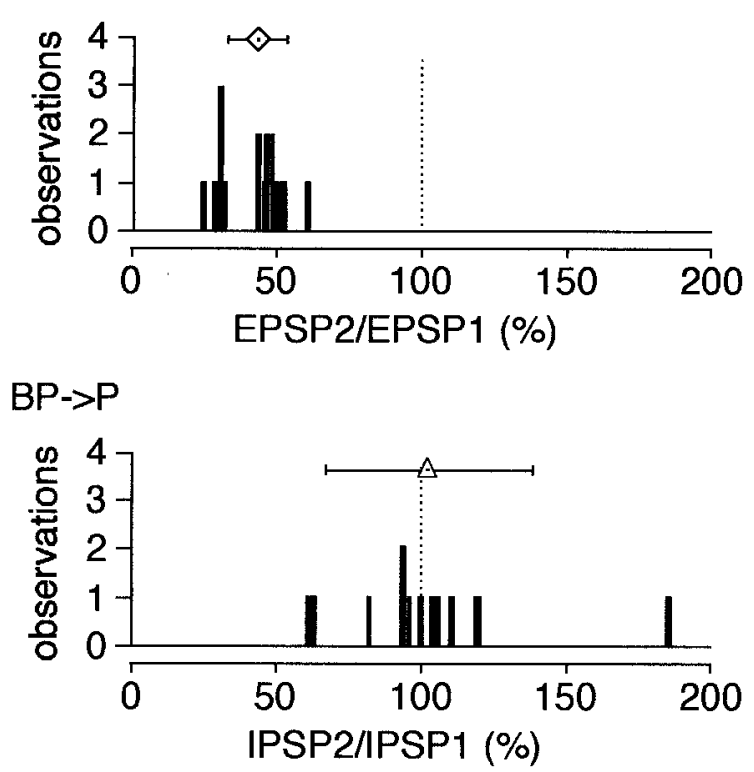

Figure 4. Reciprocal innervation in layer $2 / 3$ pyramid-bipolar-pyramid. $A$, Schematic diagram of reciprocal connections between pyramidal $(P)$ and bipolar $(B P)$ cells. $B$, Dual simultaneous recordings from reciprocally connected pyramidal and bipolar cells: EPSPs evoked by pyramidal cell terminals in postsynaptic bipolar cell ( $P \rightarrow B P$; top traces $)$ and IPSPs evoked by bipolar cell terminals in postsynaptic pyramidal cell $(B P \rightarrow P$; bottom traces). Presynaptic cells were stimulated at $10 \mathrm{~Hz}$. C, Distribution of amplitude ratios of EPSP2/EPSP1 (top histogram) and IPSP2/IPSP1 (bottom histogram). Stimulation frequency, $10 \mathrm{~Hz}$. Symbols above histograms give the mean $( \pm \mathrm{SD})$ amplitude ratios [bipolar cells, $43 \pm 10 \%$, $n=18$ (diamond); pyramidal cells, $102 \pm 36 \%, n=13$ (triangle)].
A Bipolar cell
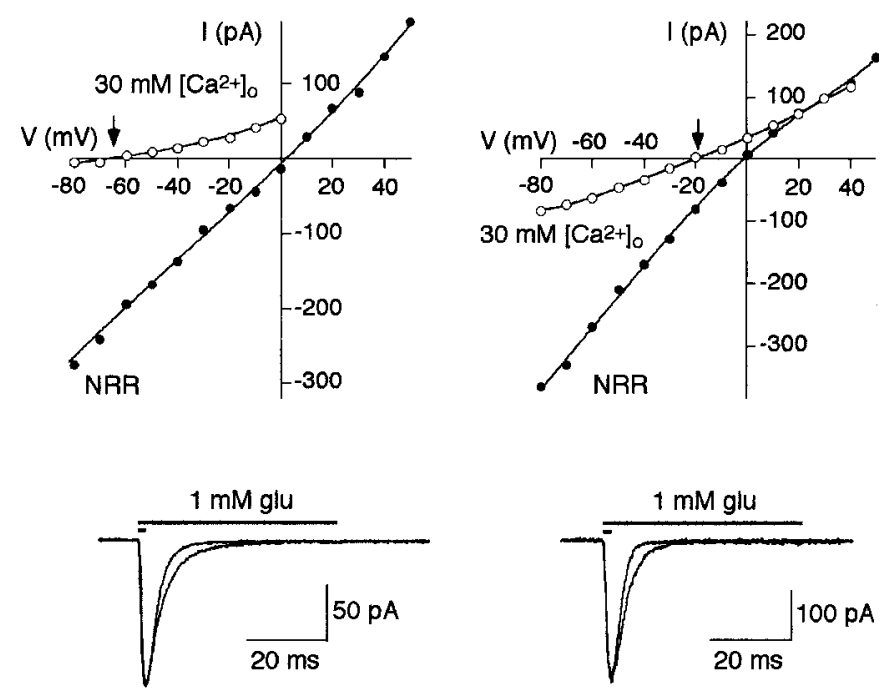

Figure 5. $\mathrm{Ca}^{2+}$ permeability, deactivation, and desensitization time course of AMPAR channels. A, Top panel, Current-voltage relations for the glutamate-evoked currents recorded from nucleated patches pulled from bipolar cells in normal rat Ringer's solution (NRR; closed circles) and high $\mathrm{Ca}^{2+}\left(30 \mathrm{~mm}\left[\mathrm{Ca}^{2+}\right]_{\mathrm{o}}\right.$; open circles $)$ solutions. Arrow indicates $\mathrm{Ca}^{2+} / \mathrm{Cs}^{+}$reversal potential. Bottom panel, Currents recorded from nucleated patch in response to 2 and $50 \mathrm{msec}$ glutamate pulses. Membrane potential, $-60 \mathrm{mV}$. Extracellular solution contained $10 \mu \mathrm{M}$ D-AP-5. $B$, Same as in $A$ for multipolar cells.

\section{Effects of cyclothiazide}

In nucleated patches pulled from either bipolar or multipolar cells, $50 \mu \mathrm{M}$ of CTZ almost completely prevented AMPAR desensitization as revealed from experiments with $50 \mathrm{msec}$ pulses of glutamate. Elevation of CTZ concentration to $100 \mu \mathrm{M}$ did not significantly change the shape of the currents (Fig. $8 A, B$ ). Thus, AMPAR channels in both types of interneurons have essentially the same sensitivity to CTZ. With 2 msec glutamate pulses $50 \mu \mathrm{M}$ CTZ increased current amplitudes similarly in both cell types and slowed the current decays, however to a different extent (Fig. $8 A, B$ ). Effects of CTZ on the paired-pulse ratio (PPR) measured using a paired-pulse interval of $100 \mathrm{msec}$ between two glutamate

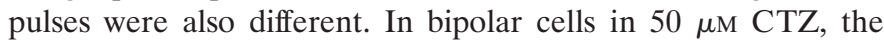
change in PPR [defined by dividing the PPRs in CTZ by the PPRs in control $\left.\left(\mathrm{PPR}_{\mathrm{CTZ}} / \mathrm{PPR}_{\mathrm{c}}\right)\right]$ was $1.96 \pm 0.26(n=4)$. Whereas in multipolar cells it was $1.19 \pm 0.05(n=3)$ (Fig. 8A). Thus, in nucleated patches CTZ has a larger effect on PPR in bipolar cells compared with multipolar cells. However, this is consistent with the removal of desensitization by CTZ and attributed to the difference in recovery time from desensitization, because in patches from both cell types PPR in the presence of CTZ was close to $1(0.92 \pm 0.05$ and $0.96 \pm 0.01$ for bipolar and multipolar cells, respectively). If AMPAR desensitization contributes to synaptic depression, one would expect similar effects of CTZ on PPD of EPSCs. In paired whole-cell recordings under control conditions, repetitive stimulation $(10 \mathrm{~Hz})$ of presynaptic pyramidal cells resulted in strong depression of EPSCs recorded from either bipolar or multipolar target cells. In the presence of CTZ $(50 \mu \mathrm{M})$ the PPD measured as the amplitude ratio of the second divided by first EPSCs evoked in bipolar cells was strongly reduced $\left(\mathrm{PPR}_{\mathrm{CTZ}} / \mathrm{PPR}_{\mathrm{c}}=1.94 \pm 0.61 ; n=4\right)$; whereas in multipolar cells the effect on PPD was minimal $\left(\mathrm{PPR}_{\mathrm{CTZ}} / \mathrm{PPR}_{\mathrm{c}}=\right.$ 
Table 2. Functional properties of somatic AMPAR channels of layer 2/3 interneurons

\begin{tabular}{lllr} 
& Bipolar depressing cell & Multipolar depressing cell & Bitufted facilitating cell \\
\hline$P_{\mathrm{Ca}} / P_{\mathrm{Na}}$ & $0.13 \pm 0.05(n=5)$ & $0.98 \pm 0.29(n=6)$ & $1.16 \pm 0.25(n=10)$ \\
$\tau$ deactivation & $2.9 \pm 0.3 \mathrm{msec}(n=12)$ & $2.7 \pm 0.2 \mathrm{msec}(n=5)$ & $2.8 \pm 0.4 \mathrm{msec}(n=5)$ \\
$\tau$ desensitization & $4.5 \pm 0.3 \mathrm{msec}(n=5)$ & $4.2 \pm 0.5 \mathrm{msec}(n=6)$ & $10.0 \pm 2.5 \mathrm{msec}(n=5)$ \\
Recovery from desensitization & $\tau_{1}=19 \mathrm{msec}(30 \%)$ & $\tau_{1}=21 \mathrm{msec}(66 \%)$ & $\tau_{1}=4.4 \mathrm{msec}(55 \%)$ \\
& $\tau_{2}=556 \mathrm{msec}(70 \%)$ & $\tau_{2}=233 \mathrm{msec}(34 \%)$ & $\tau_{2}=37 \mathrm{msec}(45 \%)$ \\
\hline
\end{tabular}
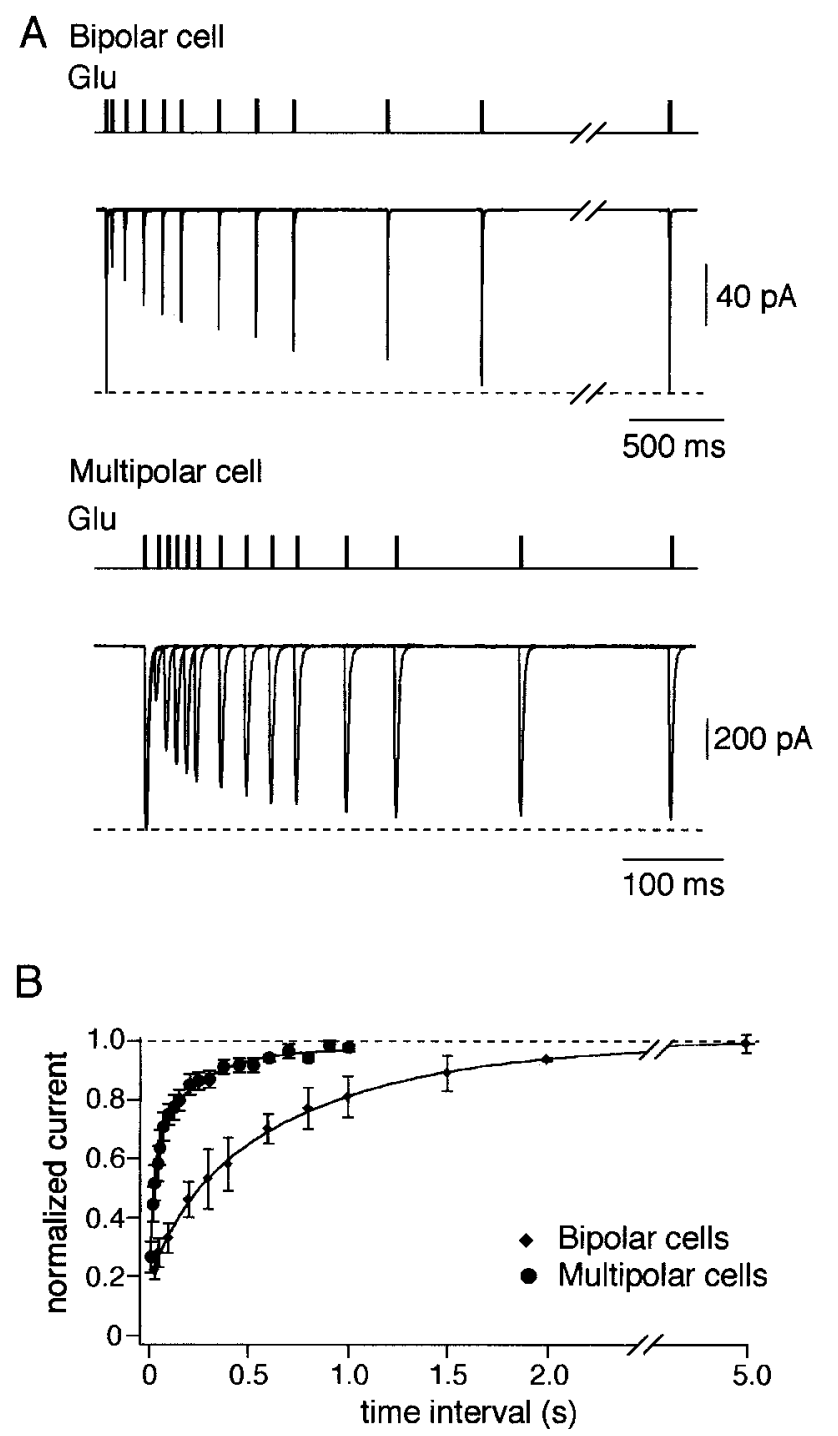

Figure 6. Recovery from desensitization of AMPAR channels. A, Overlaid glutamate-evoked currents recorded using double-pulse protocol at variable interpulse intervals in nucleated patches pulled from bipolar (top traces) and multipolar (bottom traces) cells. Duration of glutamate (1 mM) pulses was $2 \mathrm{msec}$. Membrane potential, $-60 \mathrm{mV}$. B, Time course of recovery from desensitization for the two types of interneurons measured as specified in $A$. Each point represents average of five to eight experiments. Solid lines represent double exponential fits for the data points.

$0.93 \pm 0.12 ; n=4)($ Fig. $8 B)$. In both cell types CTZ had an effect on desensitization of postsynaptic AMPARs, as indicated by the increased amplitude and longer decay times of EPSCs. It is noteworthy that changes in the kinetics of EPSCs were different in two cell types but consistent with those of the glutamate-
A Bipolar cell

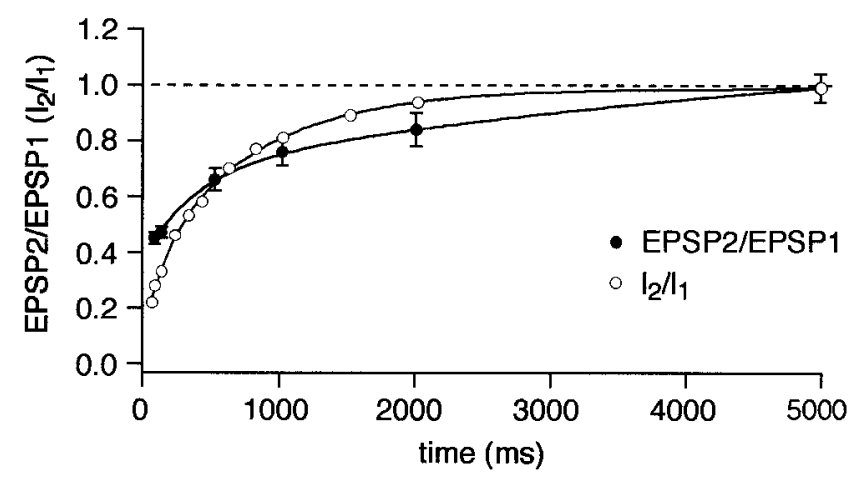

B Multipolar cell

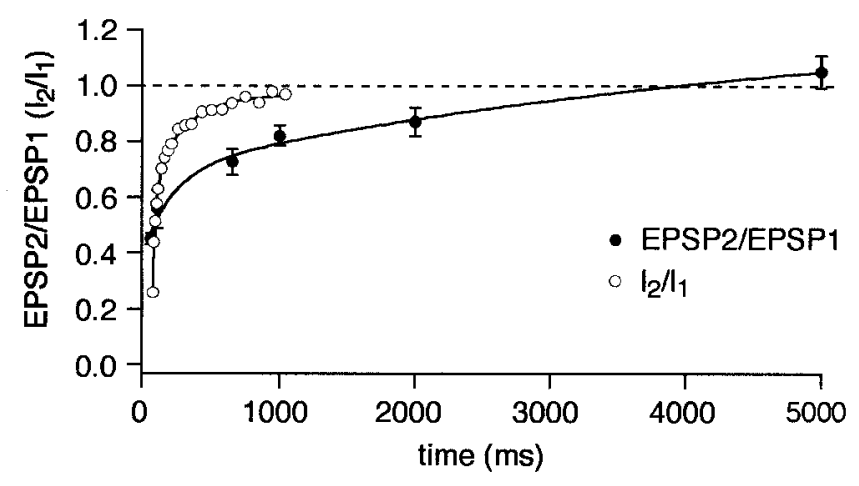

Figure 7. Recovery from synaptic depression. $A$, Time course of recovery from depression of EPSPs in bipolar cells recorded using paired-pulse stimulation of pyramidal cells at different interpulse intervals. $B$, The same as in $A$ for multipolar cells. Open symbols indicate recovery from desensitization of the glutamate-evoked currents $\left(I_{2} / I_{1}\right)$ for respective cells taken from Figure 6. Solid lines represent double exponential fits for the data points.

evoked currents in nucleated patches. Qualitatively similar effects of CTZ on PPD were observed with $100 \mu \mathrm{M} \mathrm{CTZ} \mathrm{and} \mathrm{when}$ EPSPs instead of EPSCs were recorded (data not shown). Because sensitivity of the AMPARs to CTZ in bipolar and multipolar cells appeared to be the same (Fig. 8A,B), the stronger effects of CTZ on PPD in bipolar cells suggests that in these synapses reduction of AMPAR desensitization reduced synaptic depression.

\section{Effects of AMPA and glutamate}

For doing these experiments we considered the following. At continuous presence of an agonist at low concentration there will 
A

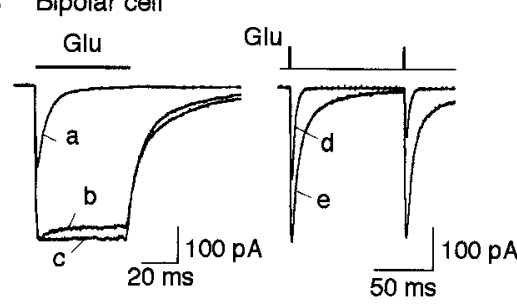

B Multipolar cell

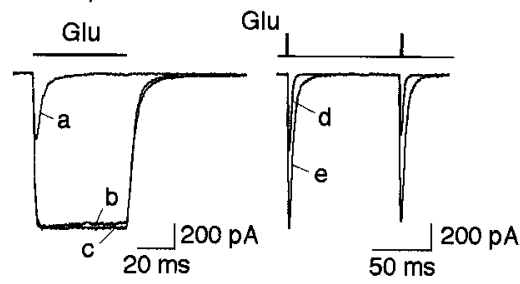

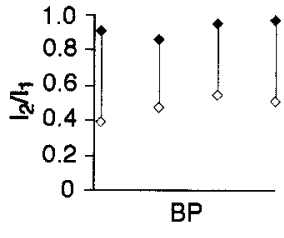

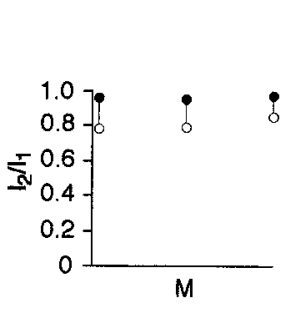

\section{C}
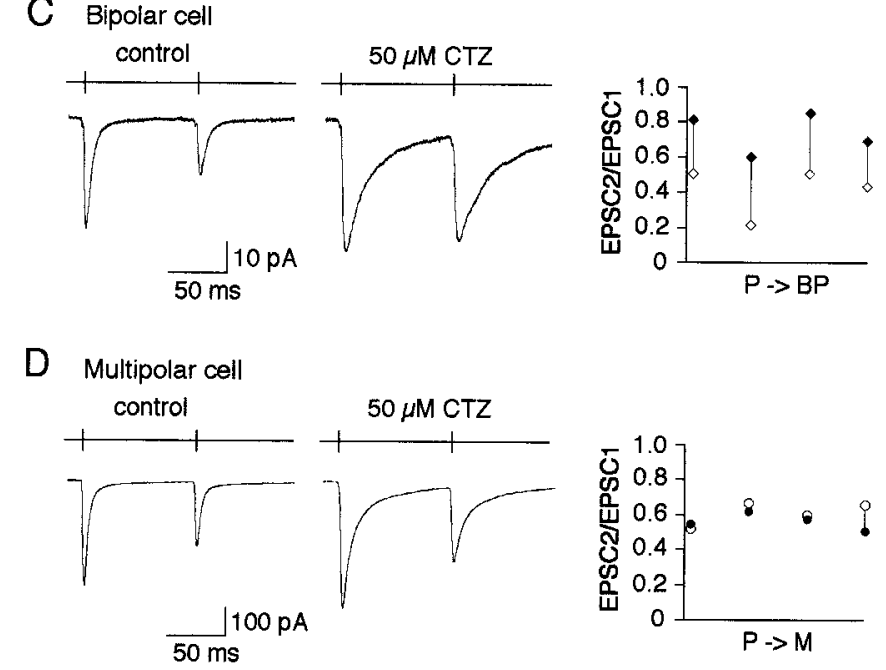

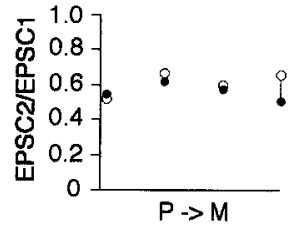

Figure 8. Effects of cyclothiazide on AMPAR desensitization and synaptic depression. A, Left, Overlaid glutamate-evoked currents recorded in the same nucleated patch pulled from a bipolar cell in control $(a)$, with $50 \mu \mathrm{M}(b)$, and $100 \mu \mathrm{M}(c)$ CTZ. Duration of glutamate (1 mM) pulses was $50 \mathrm{msec}$. Middle, Overlaid glutamate-evoked currents recorded using double pulse protocol at $100 \mathrm{msec}$ interpulse interval in the same nucleated patch pulled from a bipolar cell in control $(d)$ and with $50 \mu \mathrm{M} \mathrm{CTZ}(e)$. Duration of glutamate pulses was 2 msec. Membrane potential, $-60 \mathrm{mV}$. Right, Pairwise comparison of the current amplitude ratios $\left(I_{2} / I_{1}\right)$ in control (open symbols) and in the presence of $50 \mu \mathrm{M}$ CTZ (closed symbols) recorded from four nucleated patches. Connected symbols represent values obtained from the same patch. $B$, Same as in $A$ for patches pulled from multipolar cells. $C$, Representative recordings of EPSCs evoked in the same bipolar cell after $10 \mathrm{~Hz}$ stimulation of a presynaptic pyramidal cell in control (left) and after application of $50 \mu \mathrm{M} \mathrm{CTZ} \mathrm{into} \mathrm{extracellular} \mathrm{solution} \mathrm{(middle).} \mathrm{Pairwise} \mathrm{comparison} \mathrm{of} \mathrm{the} \mathrm{amplitude} \mathrm{ratios} \mathrm{(EPSC2/EPSC1)} \mathrm{in} \mathrm{control} \mathrm{(open} \mathrm{symbols)}$ and in the presence of CTZ (closed symbols) recorded from four cell pairs is shown on the right. Connected symbols represent values obtained from the same cell pairs. $D$, Same as in $C$ for EPSCs in target multipolar cells.

be a dynamic equilibrium between amount of desensitized and nondesensitized channels. For the channels with a slow recovery time from desensitization, this equilibrium will be shifted to a smaller amount of channels free from desensitization at any given point of time. Respectively, for the channels with a faster recovery time from desensitization a larger portion of nondesensitized channels will be available. Thus, for the channels with the slower recovery it is expected that in the presence of low agonist concentration currents activated by high concentration of glutamate will be reduced stronger compared with the control than those for the channels with a faster recovery time. How will this affect PPD in the two cases?

To understand effects of steady-state desensitization on PPD, one has to realize the main difference between channel desensitization produced by short pulse of high glutamate concentration and that induced by continuous presence of low agonist concentration. In the first case most of the channels undergo desensitization almost synchronously. Moreover, based on the curves shown in Figure 6, one can easily predict percentage of channels that will recover from desensitization and will be ready for activation at any given moment of time. However, the recovered receptors will be always just a fraction of the same channel population that has been activated and desensitized by the glutamate pulse.

In the continuous presence of AMPA or glutamate at a low concentration, the desensitization profile is absolutely different. Because the low concentration of agonist activates channels asynchronously, all subsequent steps (desensitization and recovery from desensitization) will be desynchronized as well. This would lead to the situation when at any time point some channels would be ready for activation, some would be just about to recover from desensitization, and some would be in the "deep desensitization." On the background of the low agonist concentration, a pulse of high glutamate concentration applied at a given time point will hit only the first recovered fraction of receptors and will not have any effect on the state of the channels that have been desensitized or are about to recover from desensitization. However, independently of the presence or absence of glutamate pulse within a very short time window the first available fraction desensitized by low steady-state AMPA concentration will be substituted by those channels that have been just about to recover from desensitization. Thus, very shortly after the first glutamate application almost the same number of channels (except those that have not been recovered from desensitization induced by the glutamate pulse) will be available for activation. Therefore, in the presence of the low agonist concentration paired-pulse desensitization will not be determined by the time for recovery from desensitization but partially by the fraction of the channels that are desensitized by the first glutamate pulse. In case of AMPAR channels highly sensitive to the steady-state desensitization, a brief glutamate pulse activates only a small fraction of channels that are free from steady-state desensitization (because most of the channels are desensitized by continuously present AMPA, see above). Therefore, the total current evoked by glutamate pulse at the following time point will be affected to a lesser extent than in control conditions in which all channels are desensitized by a glutamate pulse. As a result for such channels in the presence of AMPA or glutamate a smaller paired-pulse desensitization is expected than in control. For the channels with a low sensitivity to steady-state desensitization in the presence of AMPA the fraction the channels available for the first glutamate application is larger, and therefore the effect of the glutamate application on paired-pulse desensitization is much stronger and is close to that in control conditions. Thus, if strong AMPAR desensitization and its slow recovery play a role in PPD during synaptic transmission, we 
A
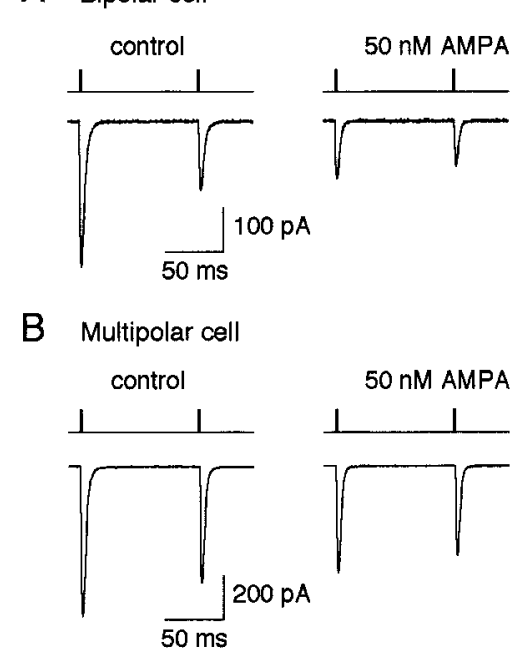
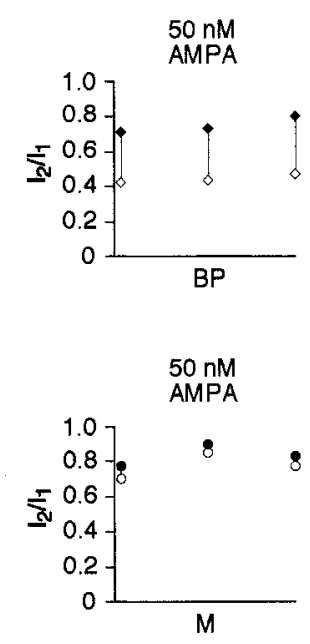

C

Bipolar cell
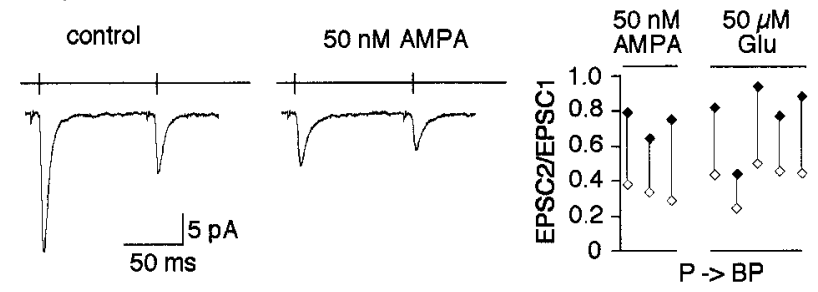

D Multipolar cell

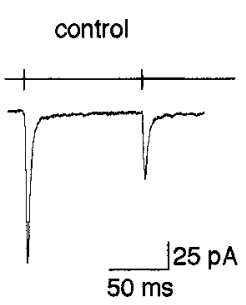

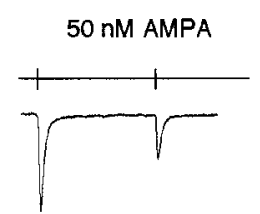

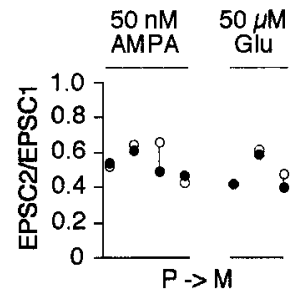

Figure 9. Effects of AMPA and glutamate on synaptic depression. A, Glutamate-evoked currents recorded using double-pulse protocol at 100 msec interpulse interval in nucleated patch pulled from a bipolar cell in control (left) and in the presence of $50 \mathrm{nM}$ AMPA (middle). Duration of glutamate pulses was $2 \mathrm{msec}$. Membrane potential, $-60 \mathrm{mV}$. Pairwise comparison of the current amplitude ratios $\left(I_{2} / I_{1}\right)$ in control (open symbols) and in the presence of $50 \mathrm{~nm}$ AMPA (closed symbols) is shown on the right. Connected symbols represent values obtained from the same patch. $B$, Same as in $A$ for patches pulled from multipolar cells. $C$, Representative recordings of EPSCs evoked in the same bipolar cell after $10 \mathrm{~Hz}$ stimulation of a presynaptic pyramidal cell in control (left) and in the presence of $50 \mathrm{nM}$ AMPA in extracellular solution (middle). Pairwise comparison of the amplitude ratios (EPSC2/EPSC1) in control (open symbols) and in the presence of $50 \mathrm{nM}$ AMPA or $50 \mu \mathrm{M}$ glutamate (closed symbols) is shown on the right. Connected symbols represent values obtained from the same cell pairs. $D$, Same as in $C$ for EPSCs in target multipolar cells.

might be able to detect this by comparing PPD in control and in the presence of low agonist concentration.

We tested these ideas first in nucleated patches. In these series of experiments we used $50 \mathrm{~nm}$ AMPA (or $50 \mu \mathrm{M}$ glutamate) for conditioning desensitization. We used these concentrations of the agonists because bath application of AMPA or glutamate at concentrations higher than $100 \mathrm{nM}$ for AMPA (or $100 \mu \mathrm{M}$ for glutamate) caused measurable depolarization of cells. Control experiments in nucleated patches showed that AMPAR channels in bipolar cells were more sensitive to steady-state desensitization than those in multipolar cells. In continuous presence of $50 \mathrm{~nm}$ AMPA the amplitude of glutamate-induced current reduced to $34 \pm 2 \%$ of control $(n=3)$ in bipolar cells and to $71 \pm 1 \%$ of control $(n=3)$ in multipolar cells. Accordingly, the PPR was reduced stronger in patches from bipolar cells $\left(\mathrm{PPR}_{\mathrm{AMPA}} / \mathrm{PPR}_{\mathrm{c}}\right.$ $=1.68 \pm 0.02 ; n=3$ ) compared with that in multipolar cells $\left(\mathrm{PPR}_{\mathrm{AMPA}} / \mathrm{PPR}_{\mathrm{c}}=1.08 \pm 0.02 ; n=3\right)$. In paired whole-cell recordings AMPA (50 nM) applied to the bath solution reduced substantially the amplitude of the first EPSC in bipolar cells (to $35 \pm 6 \%$ of control; $n=3)$ and to a lesser extent $(60 \pm 9 \%$ of control; $n=5$ ) in multipolar cells. Accordingly, EPSCs recorded from bipolar cells showed significant reduction of PPD at $10 \mathrm{~Hz}$ stimulation $\left(\mathrm{PPR}_{\mathrm{AMPA}} / \mathrm{PPR}_{\mathrm{c}}=2.26 \pm 0.41 ; n=3\right)$, whereas in multipolar cells it was virtually unaffected $\left(\mathrm{PPR}_{\mathrm{AMPA}} / \mathrm{PPR}_{\mathrm{c}}=\right.$ $0.95 \pm 0.14 ; n=5)$. Similar effects on PPD of EPSCs were observed with $50 \mu \mathrm{M}$ extracellular glutamate $\left(\mathrm{PPR}_{\mathrm{Glu}} / \mathrm{PPR}_{\mathrm{c}}\right.$ was $1.84 \pm 0.12, n=5$ and $0.92 \pm 0.09, n=3$, in bipolar and multipolar cells, respectively) (Fig. 9). These data are in line with a higher sensitivity to steady-state desensitization and a slower recovery time from desensitization of AMPAR channels expressed in bipolar interneurons. Taken together these results strongly suggest that in synapses between pyramidal and bipolar cells the desensitization of AMPAR channels contributes to synaptic depression. In comparison, in synapses between pyramidal and multipolar cells the contribution of AMPAR desensiti- zation to synaptic depression at the same given stimulation frequency $(10 \mathrm{~Hz})$ appears to be negligible.

\section{DISCUSSION}

\section{Identification of bipolar interneurons}

We describe a new local feedback circuit in cortical layer $2 / 3$ between pyramidal cells and bipolar interneurons. The bipolar interneuron is innervated by axon collaterals of neighboring pyramidal cells, and synapses show strong frequency-dependent depression of EPSPs. In contrast, the $\mathrm{GABA}_{\mathrm{A}}$ receptor-mediated IPSPs evoked in pyramids by bipolar cell stimulation have PPR close to one, suggesting that the pyramid-to-bipolar synapses determine the frequency-dependent properties of this feedback circuit.

The bipolar interneurons described here as part of a feedback circuit resemble closely one subtype (defined as IS VIPergic interneurons by Porter et al., 1998) of neocortical bipolar cells reported previously in rat cortical layers $2 / 3$ and 5 (Kawaguchi and Kubota, 1996; Porter et al., 1998; Cauli et al., 2000). They have a comparable dendritic morphology and are immunoreactive to VIP. In addition, the pattern of APs following somatic current injection is characterized by an initial burst followed by a more regular pattern of APs. They are excited by pyramids, and unitary EPSPs show frequency-dependent depression. The functional data available and the different experimental conditions (e.g., temperature, intracellular solutions) do not allow a more detailed comparison with VIP-positive IS cell subtypes (Porter et al., 1998; Cauli et al., 2000).

\section{Bipolar interneurons form a feedback circuit with pyramidal neurons}

The dendritic and axonal arbors of the bipolar cells described here span the cortex in the vertical direction. Based on the anatomy and on the functional properties, the pyramid-to-bipolar connections identify a novel reciprocal pyramid-to-interneuron 
circuit in layer $2 / 3$ additional to those described earlier (Reyes et al., 1998). This circuit presumably reduces pyramidal cell excitation in conjunction with direct thalamocortical afferents (Staiger et al., 1996) under conditions of low levels of synchronous activity. Anatomical evidence shows that part of the VIPergic terminals contact the dendrites of pyramidal cells (Peters, 1990), consistent with our reconstructions of paired cells.

\section{GluR channel properties}

The properties of AMPAR channels in bipolar cells showed striking differences compared with those expressed in other cortical interneurons. First, unlike in bitufted and multipolar interneurons the AMPAR channels in bipolar interneurons have a low $\mathrm{Ca}^{2+}$ permeability. High $\mathrm{Ca}^{2+}$ permeability of AMPAR channels was found to be one of the common properties of interneurons, whereas low $\mathrm{Ca}^{2+}$ permeability was found mainly in principal neurons (for review, see Jonas and Burnashev (1995). In this respect, the bipolar VIP-positive interneurons resemble pyramidal cells. Interestingly, Cauli et al. (2000) report high levels of GluR-B subunit-specific mRNA in IS VIPergic cells. Second, the AMPARs present in somata patches had a very slow time course of recovery from desensitization, much slower than that previously described for nonpyramidal cells in rat neocortex (Hestrin, 1993; Angulo et al., 1997; Cauli et al., 1997). Although the mechanisms that terminate synaptic currents are not known in these synapses, comparable time courses of deactivation and desensitization kinetics of glutamate-activated current suggest that desensitization of AMPARs could contribute to this process.

\section{Contribution of AMPAR channel desensitization to frequency-dependent depression}

In many neuronal connections, short-term synaptic depression is thought to be attributable primarily to presynaptic mechanisms such as depletion of vesicles at release sites, inactivation of the release apparatus, or desensitization of the $\mathrm{Ca}^{2+}$ sensor (for review, see Zucker, 1994). A postsynaptic mechanism that could contribute to the depression is GluR channel desensitization. Desensitization properties of AMPARs can be modified genetically by alternative splicing and mRNA editing (Sommer et al., 1990; Lomeli et al., 1994), and desensitization varies among AMPARs consisting of different subunit combinations that are expressed in different cell types (Mosbacher et al., 1994; Geiger et al., 1995). In chick cochlear nucleus (Trussel et al., 1993; Otis et al., 1996) and brainstem nucleus tractus solitarius neurons (Zhou et al., 1997) desensitization of postsynaptic AMPARs contributes to synaptic depression.

Usually it is difficult to discriminate between relative contribution of presynaptic and postsynaptic sites to synaptic depression, because in most cases presumably both sites are involved. In neuronal circuits described in this paper two different target cells have synaptic contacts with axons of the same projecting pyramidal neuron. This is advantageous in several respects. First, it is plausible to assume that presynaptic effects of the drugs used to modify synaptic transmission are similar at the two types of connections. Second, this allows us to make pairwise comparison of two different synaptic connections in various experimental conditions and find out a parameter that might be most relevant for the observed differences. Finally, in this study we compared data obtained from paired synaptic recordings with those obtained for patches from the two identified target cells using fast glutamate application approach.

Although the AMPAR channels expressed in bipolar and mul- tipolar cells of layer $2 / 3$ have almost the same deactivation and desensitization time course, the recovery from desensitization was much slower in bipolar cells. In these, but not in multipolar cells, extracellularly applied CTZ decreased depression, although AMPAR channels in both cell types had the same sensitivity to $\mathrm{CTZ}$ with respect to removal of desensitization. In some neuronal connections CTZ, in addition to removal of desensitization of AMPAR channels, also has presynaptic effects (Diamond and Jahr, 1995; Isaacson and Walmsley, 1996; Bellingham and Walmsley, 1999; but see Choi et al., 2000) that may affect the PPR. In CA1 hippocampal neurons, for instance, CTZ potentiates release and increases PPD (Diamond and Jahr, 1995). However, at the endbulb of Held, a fast transmitting calyx-type of synapse in the auditory pathway, CTZ reduces release and decreases PPD (Bellingham and Walmsley, 1999). Thus, based on the results of the effects of CTZ on EPSCs alone, one cannot unequivocally prove a contribution of AMPAR desensitization to PPD. In our study, however, CTZ had no or little effect on the PPR either of EPSCs or glutamate-evoked whole-soma currents recorded from multipolar interneurons. This correlates with the comparatively fast recovery from desensitization of the AMPAR channels in multipolar cells (Fig. 6). With $10 \mathrm{~Hz}$ stimulation most of the AMPARs recovered from the desensitization induced by the AP or fast glutamate application. Thus the effect of CTZ on PPD in bipolar cells most likely reflects slow recovery from desensitization of postsynaptic AMPARs, rather than a decrease of the release probability, because such an effect would have been seen also in the EPSCs recorded from multipolar cells having inputs from the terminals of the same axon. Moreover, we restricted our study of PPRs to $10 \mathrm{~Hz}$ stimulation, thus excluding at least one of the described presynaptic effects of CTZ (Bellingham and Walmsley, 1999) that is not detected after $100 \mathrm{msec}$. Additional evidence in favor of a contribution of AMPAR desensitization to PPD was obtained from experiments with steady-state desensitization of synaptic AMPAR channels. Steady-state desensitization of AMPARs reduced synaptic depression only in bipolar cells, which express AMPAR channels highly sensitive to steady-state desensitization. Thus, both the reduction of desensitization and induction of steady-state desensitization reduced depression in bipolar cells but not in multipolar cells. Moreover, both actions had comparable effects on the PPR for the currents measured in patches, under conditions when any presynaptic effect is excluded. These results strongly suggest that a substantial part of the synaptic depression in bipolar cells occurring during repetitive stimulation of pyramidal cells is attributable to the rapid and strong desensitization of AMPAR channels and their slow recovery from desensitization.

\section{Function of bipolar cells in local inhibitory circuits of cortical layer $2 / 3$}

The pyramid-to-bipolar cell circuit adds to two other reciprocal local circuits that limit pyramidal cell activity in layer $2 / 3$, the pyramid-to-bitufted and the pyramid-to-multipolar circuits (Reyes et al., 1998). The output of bipolar cells to pyramidal cells is GABAergic with only a small frequency-dependent change in inhibition. Presumably bipolar cells limit the AP output of pyramidal cells in layer $2 / 3$ under conditions different from those when the two other reciprocal circuits are active, because of differences in the frequency dependence of transmission and because of the different field span of their dendritic and axonal arbors.

Bipolar interneurons receive excitatory input from all cortical layers because of the long vertical field span of their dendrites. In 
addition, their axonal arbor extends into the infragranular layers of a putative column. Bipolar cells may function as the main inhibitory elements within the entire column, but operate only at low stimulation frequencies. They act as a low-pass filter during synchronous activity of pyramidal and thalamic cells, and in the barrel cortex for example, would be turned off during repetitive afferent activity, e.g., during $8 \mathrm{~Hz}$ "whisking" behavior of a rodent.

The dendritic and axonal arbors of bitufted interneurons are also vertically oriented. However, these cells receive facilitating input from pyramids (Reyes et al., 1998). Here the feedback inhibition increases with repetitive activation of pyramids. The pyramid-to-bitufted synapse thus acts as a high-pass filter operating mostly during repetitive afferent input, e.g., during whisking behavior recently shown to restrict the extent of the representational area of a whisker (Moore et al., 1999) in the barrel cortex.

What could be the difference in the inhibition of pyramidal neurons by multipolar and bipolar interneurons? They both receive excitatory input from pyramids that show frequencydependent depression. One functional difference might be attributable to the difference in arborization of their dendrites and axons. The field spread of multipolar cells dendrites and axons is more restricted (Reyes et al., 1998). Therefore multipolar cells may act more in individual layers e.g., in layer $2 / 3$, whereas bipolar cells may act throughout the neocortical layers because of the vertical spread of their dendrites and axons.

\section{REFERENCES}

Angulo MC, Lambolez B, Audinat E, Hestrin S, Rossier J (1997) Subunit composition, kinetic, and permeation properties of AMPA receptors in single neocortical nonpyramidal cells. J Neurosci 17:6685-6696.

Bellingham MC, Walmsley B (1999) A novel presynaptic inhibitory mechanism underlies paired pulse depression at a fast central synapse. Neuron 23:159-170.

Brusa R, Zimmerman F, Koh D-S, Feldmeyer D, Gass P, Seeburg P, Sprengel R (1995) Early-onset epilepsy and postnatal lethality associated with an editing-deficient GluR-B allele in mice. Science 270:1677-1680.

Cauli B, Audinat E, Lambolez B, Angulo MC, Ropert N, Tsuzuki K, Hestrin S, Rossier J (1997) Molecular and physiological diversity of cortical nonpyramidal cells. J Neurosci 17:3894-3906.

Cauli B, Porter JT, Tsuzuki K, Lambolez B, Rossier J, Quenet B, Audinat E (2000) Classification of fusiform neocortical interneurons based on unsupervised clustering. Proc Natl Acad Sci USA 97:6144-6149.

Choi S, Klingauf J, Tsien RW (2000) Postfusional regulation of cleft glutamate concentration during LTP at "silent synapses". Nat Neurosci 3:330-336.

Colquhoun D, Jonas P, Sakmann B (1992) Action of brief pulses of glutamate on AMPA/kainate receptors in patches from different neurones of rat hippocampal slices. J Physiol (Lond) 458:261-287.

Diamond JS, Jahr CE (1995) Asynchronous release of synaptic vesicles determines the time course of the AMPA receptor-mediated EPSC. Neuron 15:1097-1107.

Geiger JRP, Melcher T, Koh D-S, Sakmann B, Seeburg PH, Jonas P, Monyer H (1995) Relative abundance of subunit mRNAs determines gating and $\mathrm{Ca}^{2+}$ permeability of AMPA receptors in principal neurons and interneurons in rat CNS. Neuron 15:193-204.

Hestrin S (1993) Different glutamate receptor channels mediate fast excitatory synaptic currents in inhibitory and excitatory cortical neurons. Neuron 11:1083-1091.

Isaacson JS, Walmsley B (1996) Amplitude and time course of spontaneous and evoked excitatory postsynaptic currents in bushy cells of the anteroventral cochlear nucleus. J Neurophysiol 76:1566-1571.

Jonas P, Burnashev N (1995) Molecular mechanisms controlling calcium entry through AMPA-type glutamate receptor channels. Neuron 15:987-990.

Kawaguchi Y (1993) Groupings of nonpyramidal and pyramidal cells with specific physiological and morphological characteristics in rat frontal cortex. J Neurophysiol 69:416-431.

Kawaguchi Y (1995) Physiological subgroups of nonpyramidal cells with specific morphological characteristics in Layer II/III of rat frontal cortex. J Neurosci 15:2638-2655.

Kawaguchi Y, Kubota Y (1996) Physiological and morphological identification of somatostatin- or vasoactive intestinal polypeptide-containing cells among GABAergic cell subtypes in rat frontal cortex. J Neurosci 16:2701-2715.

Kawaguchi Y, Kubota Y (1997) GABAergic cell subtypes and their synaptic connections in rat frontal cortex. Cereb Cortex 7:476-486.

Lomeli H, Mosbacher J, Melcher T, Hoger T, Geiger JRP, Kuner T, Monyer H, Higuchi M, Bach A, Seeburg PH (1994) Control of kinetic properties of AMPA receptor channels by nuclear RNA editing. Science 266:1709-1713.

Markram H, Lübke J, Frotscher M, Roth A, Sakmann B (1997) Physiology and anatomy of synaptic connections between thick tufted pyramidal neurones in the developing rat neocortex. J Physiol (Lond) 500:409-440.

Markram H, Wang Y, Tsodyks M (1998) Differential signaling via the same axon of neocortical pyramidal neurons. Proc Natl Acad Sci USA 95:5323-5328.

Moore CI, Nelson SB, Sur M (1999) Dynamics of neuronal processing in rat somatosensory cortex. Trends Neurosci 22:513-520.

Mosbacher J, Schoepfer R, Monyer H, Burnashev N, Seeburg PH, Ruppersberg JP (1994) A molecular determinant for submillisecond desensitization in glutamate receptors. Science 266:1059-1062.

Otis T, Zhang S, Trussell LO (1996) Direct measurement of AMPA receptor desensitization induced by glutamatergic synaptic transmission. J Neurosci 16:7496-7504.

Peters A (1990) The axon terminals of vasoactive intestinal polypeptide (VIP)-containing bipolar cells in rat visual cortex. J Neurocytol 19:672-685.

Porter JT, Cauli B, Staiger JF, Lambolez B, Rossier J, Audinat E (1998) Properties of bipolar VIPergic interneurons and their excitation by pyramidal neurons in the rat neocortex. Eur J Neurosci 10:3617-3638.

Reyes A, Lujan R, Rozov A, Burnashev N, Somogyi P, Sakmann B (1998) Target-cell-specific facilitation and depression in neocortical circuits. Nat Neurosci 1:279-285.

Sather W, Dieudonne S, MacDonald JF, Ascher P (1992) Activation and desensitization of $N$-methyl-D-aspartate receptors in nucleated outsideout patches from mouse neurons. J Physiol (Lond) 450:643-672.

Sommer B, Keinänen K, Verdoorn TA, Wisden W, Burnashev N, Herb A, Köhler M, Tagaki T, Sakmann B, Seeburg PH (1990) Flip and flop: A cell-specific functional switch in glutamate-operated channels of the CNS. Science 249:1580-1585.

Staiger JF, Zilles K, Freund TF (1996) Distribution of GABAergic elements postsynaptic to ventroposteromedial thalamic projections in layer IV of rat barrel cortex. Eur J Neurosci 8:2273-2285.

Stuart GJ, Dodt H-U, Sakmann B (1993) Patch-clamp recordings from the soma and dendrite of neurons in brain slices using infrared video microscopy. Pflügers Arch 423:511-518.

Trussel LO, Zhang S, Raman IM (1993) Desensitization of AMPA receptors upon multiquantal neurotransmitter release. Neuron 10:1185-1196.

Zhou Z, Champagnat J, Poon C-S (1997) Phasic and long-term depression in brainstem nucleus tractus solitarius neurons: differing roles of AMPA receptor desensitization. J Neurosci 17:5349-5356.

Zucker RS (1994) Calcium and short-term synaptic plasticity. Neth J Zool 44:495-512. s 